\title{
NASILJE U OBITELJIMA I BLISKIM ODNOSIMA VOJNIKA I VOJNIH VETERANA: ČIMBENICI RIZIKA I MOGUĆNOSTI PREVENTIVNOG DJELOVANJA
}

Pregledni članak

Primljeno: veljača, 2016.

Prihvaćeno: travanj, 2016.

UDK 616.89:355.4

DOI 10.3935/ljsr.v23i2.105

Vesna Trut ${ }^{1}$

Ministarstvo obrane RH Hrvatsko vojno učilište »Dr. Franjo Tuđman"«

\section{SAŽETAK}

$U$ radu se analiziraju dostupni pokazatelji i procjenjuje prisutnost nasilničkog ponašanja u obiteljima hrvatskih vojnih veterana i aktivnih vojnika. Temeljem dostupnih podataka iz literature i specifičnosti vojne profesije analiziraju se ključni rizični čimbenici za pojavu obiteljskog nasilja u vojnoj populaciji. Posebna pozornost posvećuje se stresorima vojne profesije koji negativno djeluju na psihičko i tjelesno zdravlje vojnog osoblja kao i na ukupno obiteljsko funkcioniranje i zdravstvene ishode članova. Zbog iskustva Domovinskog rata, kritički se preispituju obilježja hrvatske vojne populacije, njihove specifičnosti i moguća povezanost s pojavom nasilničkog ponašanja. Posebni naglasak stavlja se na potrebu i mogućnosti otklanjanja ili ublažavanja ovog nepoželjnog ponašanja na različitim društvenim razinama.

${ }^{1}$ mr. sc. Vesna Trut, psihologinja, e-mail: vesna.trut37@gmail.com
Ključne riječi:

obiteljsko nasilje, nasilje u bliskim odnosima, aktivni vojnici, ratni veterani, rizični čimbenici. 


\section{UVOD}

lako se fenomen nasilja u obiteljskim odnosima javlja kroz čitavu ljudsku povijest, tek se u drugoj polovici 20. stoljeća o njemu počelo govoriti kao društvenom problemu te istraživati njegova rasprostranjenost i dugoročne štetne posljedice. O važnosti prepoznavanja tog problema i potrebi sustavnog djelovanja na svjetskoj razini najbolje svjedoči izrada strateških dokumenata od strane ključnih međunarodnih organizacija (UN, WHO, UNICEF, Vijeće Europe) s ciljem sprječavanja i zaustavljanja pojave nasilja u obitelji (Ajduković, 2004.a). Nasilje u obitelji danas se smatra jednim od globalnih problema koji je izravno povezan s narušavanjem temeljnih ljudskih prava članova obitelji (Ajduković, 2004.a; Klasnić, 2011.; WHO, 2013.). Navedeni trendovi utjecali su i na uređivanje normativnog okvira u Republici Hrvatskoj te na promjenu u pristupu problemu nasilja u obitelji. Nasilje se više ne tretira isključivo kao problem pojedinca i njegove obitelji, već se počinje naglašavati odgovornost države u poduzimanju odgovarajućih mjera (Ajduković, 2004.a) te propisuje odgovornost svih stručnjaka za prijavljivanje nasilja (Ajduković i Ajduković, 2010.).

Nasilje u obitelji predstavlja oblik interpersonalnog nasilja u koje mogu biti uključeni svi članovi obitelji, a pojedinac mu može biti izložen tijekom cijelog života. Ono obuhvaća različite oblike ponašanja čiji je temeljni cilj kontrola nad članovima obiteljske zajednice korištenjem sile, zastrašivanja i manipulacije (Ajduković i Ajduković, 2010.). Obiteljsko nasilje i nasilje u bliskim odnosima često se koriste kao sinonimi, iako obiteljsko nasilje predstavlja širi pojam i obuhvaća nasilje nad supružnicima, djecom te starijim i nemoćnim osobama u obitelji (Wallace, 2004.). Bliski odnos (veza) uključuje bilo koji romantični i/ili spolni odnos između dvije osobe, koji uključuje hodanje ili udvaranje, odnose u kojem partneri žive zajedno u istom kućanstvu, odnose u kojima dvije osobe imaju zajedničku djecu iako više nisu u formalnom, romantičnom ili seksualnom odnosu te bračne odnose (Mouradian, 2000., prema Klasnić, 2011.). Različiti oblici nasilničkog ponašanja u obitelji uključuju tjelesno, psihološko, i seksualno zlostavljanje te uskraćivanje ili zanemarivanje (WHO, 2002.), a često se javljaju istodobno te ih je stoga prilično teško jasno razgraničiti (Ajduković i Ajduković, 2010.).

U posljednjih se desetak godina promijenila perspektiva sagledavanja počinitelja nasilja u obitelji, a nasilje se počinje tretirati kao recipročno partnersko ponašanje, a žene se osim kao žrtve percipiraju i kao potencijalne počiniteljice nasilja (Sesar i Dodaj, 2014.). Unatoč postojanju obostranog nasilja, većina podataka ipak potvrđuje da su u obiteljima i intimnim vezama muškarci počinitelji velike većine nasilnog ponašanja (Ajduković i Ajduković, 2010; Klasnić, 2011.). Istraživanja obiteljskog nasilja provedena širom svijeta potvrđuju da je riječ o općem, svepri-

\section{6 članci}


sutnom i ponavljajućem problemu, kao i da su najčešće žrtve žene, djeca i starije osobe (WHO, 2013.). Rezultati istraživanje Svjetske zdravstvene organizacije pokazuju da je preko $35 \%$ žena diljem svijeta bilo izloženo tjelesnom i/ili seksualnom nasilju kojeg su najčešći počinitelji njihovi intimni partneri. Osim toga, u preko 38\% od ukupnog broja svih slučajeva smrtnog stradavanja žena, počinitelji su također njihovi partneri (WHO, 2013.). Istraživanje provedeno u zemljama Europske unije pokazuje da je prosječno $22 \%$ europskih žena u dobi od petnaeste godine života izloženo tjelesnom i/ili seksualnom nasilju svojih partnera, pri čemu se među pojedinim članicama EU-a zastupljenost nasilja kreće u rasponu od 13\% do 32\% (European Union Agency for Fundamental Rights, 2014.). Tjaden i Thoennes (2000.) navode da je u nekom životnom razdoblju nasilju u obitelji bilo izloženo oko $25,5 \%$ žena i 7,9\% muškaraca. S obzirom na opći trend porasta prijavljivanja slučajeva obiteljskog nasilja, takvi se pokazatelji očekuju i u Hrvatskoj iako mali broj epidemioloških istraživanja u hrvatskoj populaciji otežava cjelovit uvid u ovu problematiku. U retrospektivnom istraživanju Buljan Flander (2007.) nalazi da je tijekom djetinjstva 15,9\% hrvatskih ispitanika bilo izloženo tjelesnom nasilju, 16,5\% emocionalnom zlostavljanu, 14,8\% ispitanika svjedočilo je nasilju u obitelji, a 14\% ih je spolno zlostavljano. Otročak (2003.) iznosi podatak da je nasilju u partnerskim odnosima izloženo približno $29 \%$ hrvatskih žena. Podaci nadležnih tijela u Hrvatskoj govore o porastu broja prijavljenih slučajeva nasilja u obitelji za razdoblje od 1995. do 2008. godine (Ajduković i Ajduković, 2010.).

Metaanaliza četrnaest istraživanja provedenih u američkoj vojsci omogućava bolje razumijevanje raširenosti obiteljskog nasilja u vojnoj populaciji (Rentz i sur., 2006.). Usporedba rezultata jedanaest istraživanja zlostavljanja djece u američkim vojnim obiteljima provedenih od 1971. do 1999. godine pokazuje kako je tjelesno nasilje najčešći oblik nasilja i kreće se u rasponu od 31,3\% do 70,8\% svih utvrđenih slučajeva nasilja. Slijedi ga zanemarivanje djece koje se u ukupnom broju utvrđenih slučajeva javlja u rasponu od 18,5 do $50 \%$, spolno nasilje $(6,1 \%-17,8 \%)$ te emocionalno nasilje $(0,7 \%-15,6 \%)$. $U$ analizi podataka nasilja američke vojne i civilne populacije za razdoblje od 2003. do 2013. godine Milner (2015.) nalazi da je ukupna stopa zlostavljanja djece u vojnim obiteljima dvostruko manja od civilne stope. Smatra da takvim pokazateljima uvelike pridonosi značajno niža stopa zanemarivanja djece $u$ vojnim obiteljima, što povezuje $s$ boljom ekonomskom potporom koju pruža vojska čime se smanjuje rizik zanemarivanja. Manje je istraživanja koja se bave nasiljem među supružnicima, a usporedba rezultata tri istraživanja provedena od 1988. do 2000. godine u američkoj vojsci upućuje na tjelesno nasilje kao najčešći oblik nasilja, a čini $89,3 \%$ do $92,4 \%$ svih potvrđenih slučajeva nasilja. Rumm i sur. (2000., prema Rentz i sur., 2006.) nalaze da je tjelesno zlostavljanje djece dva puta češće u obiteljima u kojima je prisutno partnersko nasilje, kao i da 
je u takvim obiteljima veća vjerojatnost pojavljivanja spolnog nasilja nad djecom. Usporedba učestalosti partnerskog nasilja u vojnim u odnosu na civilne obitelji pokazuje veću stopu tjelesnog nasilja u vojnoj populaciji (Cronin, 1995.; Griffin i Morgan, 1988., prema Rentz i sur., 2006.) ili više slučajeva težih oblika agresivnog ponašanja muškaraca prema suprugama i partnericama (Heyman i Neidig, 1999., prema Rentz i sur., 2006.).

S obzirom na činjenicu da tema obiteljskog nasilja u hrvatskoj vojnoj populaciji do sada nije istraživana, ovaj se rad usmjerava na to područje. Cilj rada je da se pregledom dostupne literature analiziraju najvažniji čimbenici povećanog rizika za pojavu nasilja u obiteljima i bliskim odnosima vojnika. Radom se nastoje problematizirati rizični čimbenici za pojavu nasilnog ponašanja u hrvatskoj vojnoj populaciji. Preispituju se ključna obilježja hrvatske vojne populacije kao i njihova moguća povezanost s pojavom nasilja u obiteljima hrvatskih vojnih veterana i djelatnih (aktivnih) vojnika. Radom se nastoji senzibilizirati javnost i odgovorne institucije na potrebu i mogućnosti preventivnog djelovanja, a stručnjake potaknuti na istraživačku aktivnost i predlaganje konkretnih mjera.

\section{RIZIČNI ČIMBENICI ZA POJAVU NASILJA U OBITELJIMA I BLISKIM ODNOSIMA VOJNIKA}

Nasilje u obitelji i bliskim odnosima nesumnjivo predstavlja ozbiljan socijalni problem jer je riječ o pojavi koja je društveno uvjetovana, predstavlja stvarnu ili doživljenu prijetnju društvenim vrijednostima te postoje mogućnosti poboljšanja ili otklanjanja tog problema zajedničkom akcijom društva u cjelini (Ajduković, 2008.). Iz malobrojnih istraživanja ove problematike u hrvatskoj populaciji teško je zaključivati o stvarnim razmjerima problema kao i najboljim načinima njegovog rješavanja. S druge strane, okolnosti u kojima je stvarana država i neka aktualna obilježja hrvatskog društva nameću potrebu ozbiljnijeg promišljanja ove teme. Hrvatsko društvo nije samo postkonfliktno i posttranzicijsko društvo, već i društvo koje se duže vrijeme suočava s izraženim problemima ekonomske i osobne nesigurnosti, nezaposlenosti, kriminala i netolerancije, a svi navedeni čimbenici pridonose većoj pojavi obiteljskog nasilja (Dokmanović, 2007., prema Klasnić, 2011.). Prethodno spomenuta istraživanja (Rentz i sur., 2006.; Milner, 2015.) jasno upućuju na rizik prisutnosti nasilja i u vojnim obiteljima, kao i na potrebu poduzimanja sustavnih intervencijskih mjera.

Brojni su teorijski pristupi koji nastoje rastumačiti uzroke nasilnog ponašanja ljudi. Neke od njih predstavljaju unidimenzionalne teorije (poput teorije društvenog učenja, teorije resursa ili feminističkih teorija) dok su druge multidimenzionalne i uzroke nasilja vide u složenim obrascima interakcije više čimbenika na ra-

\section{8 članci}


zličitim razinama (poput socijalno-ekološke teorije) (Klasnić, 2011.). Tako Carlson (1984., prema Klasnić, 2011.) nasilje određuje kao posljedicu međusobnog djelovanja osobnih, situacijskih i sociokulturalnih čimbenika, a modificirani model u svojim istraživanjima koristi i Svjetska zdravstvena organizacija. Prema tom modelu, postoje četiri razine čimbenika koji uključuju individualnu razinu (biološka i osobna obilježja), razinu veze (čimbenici koji su rezultat interpersonalnih odnosa), razinu zajednice (kontekst u kojem se odnosi odvijaju) i razinu društva (sustave vrijednosti, društvene norme, socijalno-ekonomske prilike) (WHO, 2002.).

Rizični čimbenici za koje je nađeno da povećavaju vjerojatnost nasilnog ponašanja u obitelji u općoj populaciji uključuju nisku razinu obrazovanja, niske obiteljske prihode, iskustvo nasilja u djetinjstvu, mušku dominaciju u obitelji, bračne sukobe, ekonomske probleme, siromaštvo, nizak društveni kapital, slabe sankcije prema nasilju, tradicionalne rodne uloge i društvene norme koje odobravaju ili potiču nasilje (WHO, 2002.). Oni se odnose i na pripadnike vojne populacije, međutim s obzirom na prirodu vojnog poziva može se pretpostaviti i postojanje nekih dodatnih rizičnih čimbenika. Clark i Messer (2006.) navode da za pojavu nasilja u obiteljima i bliskim vezama vojnika na individualnoj razini dodatan čimbenik rizika predstavlja prisutnost PTSP-a, na razini odnosa zloporaba alkohola, a na razini zajednice stresori vojne profesije i sustav vrijednosti koji dijele pripadnici vojne organizacije (organizacijska kultura). Zbog boljeg razumijevanja i dobivanje cjelovitog uvida u problematiku pojave nasilja u obiteljima vojnika, u nastavku rada usmjerit ćemo se upravo na neka od ključnih obilježja vojne profesije.

Pojava obiteljskog nasilja u vojnoj populaciji prije svega se može povezati s prirodom vojne profesije koja povećava razinu ukupnog stresa kojem su izložene obitelji vojnika i narušava njihovo obiteljsko funkcioniranje (Clark i Messer, 2006.; Milner, 2015.). Za vojni je poziv uobičajen prekovremeni rad, česta razdvojenost obitelji zbog različitih oblika vojne obuke i izobrazbe ili sudjelovanja u vojnim operacijama. Osim toga, zbog potrebe radnog mjesta, vojno je osoblje češće izloženo premještajima na nove dužnosti koje uključuju i drugo mjesto (grad, državu) službe što često rezultira narušavanjem obiteljskog života (Gerlock, 2004.). Razdvojenost predstavlja dodatan izvor stresa za vojnika, ali i preostale članove obitelji, osobito supruge, jer osim narušavanja obiteljske rutine, podrazumijeva i preuzimanje novih obiteljskih uloga i rast odgovornosti (Segal, 1989.; Milner, 2015.). Osim toga, u obitelji je u određenoj mjeri stalno prisutna zabrinutost i neizvjesnost zbog mogućih opasnosti kojima je izložen izočni član obitelji. Česta i dugotrajna razdvojenost narušava kvalitetu bračnih odnosa, što je osobito opasno za mlađe parove (Newby i sur., 2005.).

Osim toga, zbog zadaća koje obavljaju, vojnici su izloženi i dodatnom profesionalnom stresu (Gerlock, 2004.). Bilo da je riječ o tradicionalnim ili suvremenim 
vojnim operacijama, njihovo je zajedničko obilježje izloženost vojnika nasilju i životnoj opasnosti te sudjelovanje u različitim oblicima bojnog (borbenog) djelovanja. Bojni stres, koji se u određenoj mjeri javlja u svim bojnim operacijama, smatra se glavnim uzrokom pojave psihičkih poremećaja vojnika. Višestruki izvori bojnog stresa ne uključuju samo život u strahu od smrti, već i rizik osobnog ranjavanja i pogibije, nazočnost stradavanjima i patnji drugih vojnika i civila te, možda najvažnije, usmrćivanje drugih ljudi (Quinn i Quinn, 2011.). Dugotrajna izloženost bojnim stresorima izaziva emocionalno i tjelesno iscrpljivanje vojnika i mijenja način njegova razmišljanja i suočavanja sa stresom. Posljedice se manifestiraju u obliku bojnih stresnih reakcija, među kojima posttraumatski stresni poremećaj (PTSP) predstavlja najteži oblik (Pavlina, Filjak i Bender-Horvat, 2000.). Istraživanja pokazuju da neliječeni PTSP postaje »razvojna psihopatologija« sa socijalnim i emocionalnim poteškoćama koje su prisutne tijekom čitavog života (Teten i sur., 2010., prema Quinn i Quinn, 2011.). Problemima vojnika sa simptomima PTSP-a često se pridružuju i drugi psihopatološki simptomi (Foy, 1994.). Griange (2003., prema Quinn i Quinn, 2011.) nalazi da 80\% oboljelih ima najmanje još jedan psihički poremećaj. Tijek PTSP-a kroz duže vremensko razdoblje nije u potpunosti jednoznačan. Većina oboljelih zadržava značajne simptome poremećaja nekoliko godina, postupno se oporavljaju i adekvatno funkcioniraju uz povremeno pojavljivanje slabih prethodnih simptoma (Vračić, 2005.). Ipak, u ovoj je populaciji značajno smanjena tolerancija na stres kao i veća vjerojatnost pogoršavanja simptoma PTSP-a pri izlaganju bilo kojoj novoj traumi. Određeni broj oboljelih zadržava visoki stupanj izraženosti simptoma tijekom mnogo godina ili im je funkcioniranje doživotno otežano (Vračić, 2005.). Zbog povezanosti simptoma PTSP-a s pojavom nasilnog ponašanja u vojnoj populaciji, taj će se odnos detaljnije pojasniti u nastavku poglavlja.

\section{PTSP i nasilje u obiteljima vojnika}

Foy (1994.) navodi kako je rasprostranjenost PTSP-a u vojnoj populaciji visoke razine izloženosti na bojištu između 15\% i 50\%. U nacionalnom američkom istraživanju ratnih veterana Jordan i sur. (1991., prema Foy, 1994.) nalaze da je 30\% ispitanika imalo simptome PTSP-a tijekom života, dok su kod $15,2 \%$ veterana simptomi utvrđeni u trenutku ispitivanja. Oko četvrtine američkih veterana koji su do 2005. godine sudjelovali u vojnim operacijama u Afganistanu i Iraku ima dijagnozu nekog od psihičkih poremećaja, a veterani u dobi od 18 do 24 godine značajno su rizičnija skupina u odnosu na one starije od 40 godina (Seal i sur., 2007., prema Straits-Trőster i sur., 2011.). Broj američkih veterana operacija u Iraku i Afganistanu s dijagnozama psihičkih poremećaja u 2008. godini porastao je do 35\% (Cohen i sur., 2009., prema Straits-Trőster i sur., 2011.). Istraživanje provedeno u hrvatskoj

\section{0 članci}


vojnoj populaciji (Gustović-Ercegović i Komar, 1994.) navodi izraženost simptoma PTSP-a kod 14 do 31\% hrvatskih vojnika. Utvrdili su najveću izraženost PTSP-a kod demobiliziranih u odnosu na mobilizirane vojnike, a najmanju izraženost simptoma u pripadnika gardijskih brigada. $U$ istraživanju provedenom na uzorku 3217 hrvatskih veterana iz Domovinskog rata nađeno je da 16,2\% veterana ima potpuno razvijeni PTSP, a da $25 \%$ veterana ima prisutne neke od simptoma poremećaja (Komar i Vukušić, 1999.).

Značajan broj vijetnamskih veterana koji pokazuju simptome PTSP-a pokazuje i perzistentne poremećaje $u$ odnosima s bliskim osobama što se očituje u bračnim nesuglasicama, obiteljskom nasilju i zlostavljanju partnera (Clark i Messer, 2006.). $\mathrm{U}$ odnosu na veterane bez izraženih simptoma, vijetnamski veterani s izraženim simptomima PTSP-a imaju lošiju kvalitetu bračnih odnosa i veću vjerojatnost iskazivanja agresivnog ponašanja u partnerskim odnosima (Taff i sur., 1999.) te značajno veću razinu bračnih, roditeljskih i drugih problema prilagodbe, uključujući i nasilje (Kulka i sur., 1990., prema Straits-Trőster i sur., 2011.). Holbrook (2011.) navodi kako su nasilna djela u vijetnamskih veterana s PTSP-om skoro četiri puta češća u odnosu na one bez PTSP-a. Podaci istraživanja o zdravstvenim tegobama i problemima prilagodbe u veterana ratova u Afganistanu i Iraku pokazuju slične trendove. Prikupljeni podaci pokazuju da veterani u kojih su u okviru simptomatologije PTSP-a prisutni simptomi pobuđenosti, slično kao i vijetnamski veterani, vrlo teško kontroliraju agresivne impulse, ljutnju i nasilno ponašanje (Elbogen, i sur., 2010., prema Holbrook, 2011.). Kvalitativno istraživanje provedeno u toj populaciji također je pokazalo da za većinu veterana i veteranki glavne probleme predstavljaju slabija kontrola ljutnje i iritabilnost, što se onda reflektira na sve obiteljske odnose (Straits-Trőster i sur., 2011.).

Nalazi o većoj učestalosti agresivnog i nasilnog ponašanja nađeni su i u istraživanju provedenom na populaciji hrvatskih veterana, sudionika borbenih operacija tijekom Domovinskog rata. Hrvatski veterani oboljeli od PTSP-a češće izražavaju agresivnost i nasilno ponašanje $u$ odnosu na hrvatske veterane bez simptoma PTSP-a (Begić i Jokić-Begić, 2001.). Intenzivniji PTSP povezan je s eksternaliziranim simptomima kao što su acting out, neprijateljstvo i nepovjerenje, dok je blaži oblik PTSP-a većinom povezan s depresivnim simptomima (Begić i Jokić-Begić, 2007.). Kalebić Jakupčević i Ajduković (2011.) nalaze da su očevi oboljeli od PTSP-a značajno rizičniji za tjelesno zlostavljanje vlastite djece, a pokazuju i značajno narušene partnerske odnose uz učestalije sukobe koji uključuju fizičku agresiji i uvrede. Milner i Dopke (1997., prema Kalebić Jakupčević i Ajduković, 2011.) veći rizik zlostavljanja djece od strane očeva oboljelih od PTSP-a objašnjavaju njihovim slabijim kapacitetima rješavanja problema, smanjenom tolerancijom i poteškoćama u kontroli impulsa. Postojanje većeg rizika za zlostavljanje djece od strane roditelja obo- 
ljelih od PTSP-a povezuje se s nalazima istraživanja prema kojima trauma i borbeni PTSP uzrokuju slabiju privrženost i češće agresivno ponašanje prema članovima obitelji (O'Donnell i sur., 2006.).

Sve navedene spoznaje usmjeravaju nas na preispitivanje fenomena nasilja u hrvatskoj vojnoj populaciji, kako o učestalosti nasilnog ponašanja u obiteljima i bliskim odnosima vojnika tako i o čimbenicima rizika za njihovo pojavljivanje i mogućnostima preventivnog djelovanja.

\section{PRISTUP POJAVI OBITELJSKOG NASILJA U HRVATSKOJ VOJNOJ POPULACIJI}

\section{Nasilje u obitelji i braniteljska populacija}

Vojnici koji se vraćaju iz rata predstavljaju posebnu socijalnu skupinu, a problemi njihova povratka u mirnodopsku zajednicu prisutni su u svim društvima. To zasigurno vrijedi i za hrvatske veterane Domovinskog rata, osobito kada se u obzir uzmu razmjeri ratnih stradanja. U ratu je sudjelovalo 502678 branitelja, ranjeno ili ozlijeđeno ih je 30 141, a zbog posljedica sudjelovanja u ratu 57212 branitelja ima utvrđen status hrvatskog ratnog vojnog invalida (Ministarstvo branitelja, 2014.). Procjenjuje se da je oko $25 \%$ svih stanovnika Hrvatske tijekom rata bilo izloženo izravnom ratnom stresu, čemu treba pridodati i procjenu sekundarno traumatiziranih građana (Lončar i sur., 2014.). Ovakvi razmjeri stradanja u (maloj) hrvatskoj populaciji izazvali su promjene koje su značajno poremetile uobičajeno funkcioniranje svih dijelova društva (Trlek, Pavlina i Trut, 2003.). Po povratku iz rata, hrvatski su se vojnici suočavali sa zdravstvenim poteškoćama kao rezultat ranjavanja, invalidnosti ili tjelesnih oboljenja, ali i s psihičkim posljedicama koje u najvećoj mjeri uključuju PTSP kao i niz drugih nespecifičnih psihičkih poteškoća. Može se pretpostaviti da je ponovna prilagodba u ratom promijenjenu okolinu, kako obiteljsku tako i društvenu, većini branitelja predstavljala najveći izazov. O ozbiljnosti problema prilagodbe dovoljno govore dramatični službeni podaci o samoubojstvima hrvatskih branitelja prema kojima se od 1991. do konca 2014. godine ubilo najmanje 2734 hrvatskih branitelja (Komar i Koić, 2015.).

Nepovoljne društvene okolnosti ratne i poslijeratne Hrvatske u društvu su percipirane kao potencijalna prijetnja u smislu negativnih posljedica na osobnoj, obiteljskoj i razini zajednice. Razvojačeni branitelji, osobito ranjenici i oboljeli od PTSPa već su tijekom rata percipirani kao osobito rizična skupina, pa je 1995. godine započelo osnivanje centara za psihosocijalnu pomoć sudionicima i stradalnicima Domovinskog rata. Osim toga, Vlada RH je 1999. godine usvojila »Nacionalni pro-

\section{2 članci}


gram psihosocijalne i zdravstvene pomoći« (Lončar i sur., 2014.). Međutim, sve te aktivnosti u društvu nisu pokrenule proces djelotvornih promjena. Izostale su učinkovite promjene na individualnom planu (traženje stručne pomoći, razvoj psihološke otpornosti, razvoj novih vještina...), promjene u njihovom socijalnom životu (povećanje socijalne mreže...) i razvoju društvenih mjera podrške (prekvalifikacija, zapošljavanje i sl.). Nasuprot tomu, braniteljima se kao rješenje »nametnula« mogućnost ranijeg umirovljenja i ostvarivanja različitih, uglavnom materijalnih beneficija. Takav je pristup vjerojatno pridonio kumuliranju rizičnih okolnosti i razvoju brojnih nepovoljnih ishoda za pripadnike braniteljske populacije, njihove obitelji, zajednice i čitavo društvo. Narušeno psihičko i tjelesno zdravlje, invaliditet, nejednaka dostupnost stručne pomoći i programa, zloporaba alkohola, sužena socijalna mreža i socijalna isključenost $u$ hrvatskoj veteranskoj populaciji predstavljaju otežavajuće okolnosti ili socijalne rizike. Oni djeluju u međusobnoj interakciji te izazivaju i otežavaju njihovo individualno i socijalno funkcioniranje. To potvrđuju i rezultati istraživanja Anton (2005.) koja nalazi da hrvatski ratni veterani oboljeli od PTSP-a, a kojima je zbog intenzivnih simptoma oboljenja potvrđena radna nesposobnost, slabije funkcioniraju u roditeljskim ulogama, manje sudjeluju u obiteljskim poslovima i općenito lošije socijalno funkcioniraju. $U$ dijelu braniteljske populacije došlo je do razvoja »lanca rizika«, odnosno procesa u kojem su određeni rizični čimbenici tijekom vremena pridonijeli povećanju njihove ranjivosti u različitim životnim područjima. Na taj je način došlo do interakcije nekih individualna obilježja (invalidnost, PTSP, demobilizacija, gubitak posla...) sa socijalnim rizicima na makrorazini (ekonomska kriza, pretvorba i privatizacija, nezaposlenost...).

$\mathrm{U}$ tom kontekstu trebalo bi analizirati i pojavu nasilja u braniteljskim obiteljima. Ono nikada nije sustavno praćeno, a o njemu se zna uglavnom na temelju medijskih izvješća tragičnih primjera obiteljskih sukoba. U javnosti i nadležnim službama ne negira se njegova pojavnost, ali izostanak sustavnog praćenja i pristupa njegovom rješavanju svjedoči o nedovoljnoj svjesnosti o štetnosti te pojave i njezinim uzrocima. Nasilje u braniteljskim obiteljima nužno je povezati s pristupom rješavanja psihičkih posljedica rata kod ratnih stradalnika. Nažalost, Ministarstvo branitelja tek je 2014. godine donijelo odluku o osnivanju Nacionalnog centra za psihotraumu, koji bi uz Klinički odjel i Centar za krizna stanja trebao uključivati i Centar za znanstveno-istraživačke projekte (Lončar i sur., 2014.). Poznato je da bez znanstveno-istraživačke djelatnosti nema dobrog razumijevanja, obrazovanja stručnjaka, prevencije i liječenja PTSP-a niti poboljšanja ukupne kvalitete življenja ciljanih skupina i opće populacije. Razloge je moguće potražiti u činjenici da se braniteljska populacija, opterećena brojnim psihosocijalnim problemima, u jednom trenutku u hrvatskom društvu počela percipirati kao »problematična populacija«. Prema postmodernističkoj paradigmi, velika je važnost uporabe jezika (Ajdu- 
ković, 2008.), a jezik kojim se u medijima i političkim raspravama opisuju branitelji kreirao je njihovu stvarnost, odredio pristup rješavanju njihovih nepovoljnih životnih okolnosti i otežao međusobnu komunikaciju. Situaciju dodatno usložnjavaju i razlike u atribuiranju uzroka njihovih problema. Ukoliko se samim braniteljima pripišu uzroci svih njihovih problema, izostaje društvena potpora iako im je ona nužna jer je nedovoljno dobivaju u obitelji i neposrednoj okolici. Nasilje u hrvatskim braniteljskim obiteljima na različitim razinama društva većinom se percipira kao njihov individualni i obiteljski problem, a ne kao posljedica društvenih odnosa pa i ne čudi manjak učinkovitih intervencija. S druge strane, većina branitelja uzroke svih svojih problema pripisuju isključivo državi, pa teško traže i/ili prihvaćaju druge vrste potpore osim »zasluženih mirovina i stečenih prava«, unatoč tomu što oni ne pridonose rješavanju svih njihovih problema. Važno je napomenuti i da branitelji koji su bili izloženi visokoj traumatizaciji mogu imati ograničene kapacitete za promjene. Naime, kognitivno funkcioniranje visoko traumatiziranih pojedinaca je često drugačije i otežano, a individualni oporavak je vrlo spor (van den Kolk, Mc Farlane i Weisaeth, 2007., prema Ajduković, 2008.). To može biti razlogom njihovog općenito težeg prihvaćanja osobne odgovornosti za svoje stanje i ponašanje, što opet usporava njihov individualni oporavak. Osim toga, nameće se i pitanje kvalitete komunikacije uključenih dionika koja je pokazatelj manjkave kulturne kompetencije u neposrednom radu stručnjaka s korisnicima koji dolaze iz »braniteljske kulture « (Žganec i Miljenović, 2011.). U radu s veteranima i njihovim obiteljima većim je dijelom izostala praksa partnerskih odnosa svih dionika, a socijalna se stvarnost nije definirala kroz zajednički napor pogođenih pojedinaca, pomagača i donositelja odluka. Stječe se dojam da je većina mjera i intervencija uglavnom bila rezultat ad hoc donesenih političkih odluka, što nije pridonijelo rješavanju, već kumuliranju nepovoljnih okolnosti i stvaranju novih socijalnih rizika.

\section{Nasilje u obitelji i djelatni vojnici}

Osim u veteranskim obiteljima, nasilje se javlja i u obiteljima djelatnih vojnika. U hrvatskom obrambenom sustavu se svi događaji obiteljskog nasilja u kojima su sudjelovali pripadnici sustava smatraju izvanrednim događajima. Takvi se događaji redovito evidentiraju, a ovisno o vrsti događaja, pokreću se aktivnosti iz djelokruga rada Vojne policije i Vojnostegovnog suda. Nakon saznanja o počinjenju djela ili po dojavi civilne policije, pripadnici Vojne policije dužni su izraditi službenu zabilješku i obavijestiti nadređenog zapovjednika o povredi vojne stege, a nakon toga obavezno se pokreće i postupak utvrđivanja stegovne odgovornosti počinitelja. Svi podaci o počiniteljima izvanrednih događaja u vojsci imaju oznaku tajnosti i njihova je upotreba ograničena, što vrijedi i za evidentirane slučajeve nasilja u obite-

\section{4 članci}


ljima djelatnih vojnika. Podaci koji su nam dostupni navedeni su tijekom stručnog savjetovanja o problematici obiteljskog nasilja organiziranog za ključno osoblje Ministarstva obrane i Oružanih snaga RH u srpnju 2016. godine. U razdoblju od 01. siječnja 2011. do 31. ožujka 2016. godine slučajevi obiteljskog nasilja činili su oko $10 \%$ ukupnog broja svih izvanrednih događaja, a u $88 \%$ slučajeva riječ je o djelima koja imaju obilježja prekršaja. Što se tiče obilježja počinitelja nasilničkog ponašanja, u gotovo svim slučajevima riječ je o muškim počiniteljima, većinom vojnicima i dočasnicima, a rjeđe časnicima i vojnim namještenicima. Najvećim dijelom riječ je o nasilničkom ponašanju prema supruzi i/ili nevjenčanoj supruzi, a rjeđe prema drugim članovima obitelji, djeci i bivšoj supruzi. U $43 \%$ svih evidentiranih slučajeva utvrđena je zloporabe alkohola tijekom nasilničkog ponašanja.

Pojava obiteljskog nasilja u vojnoj populaciji uglavnom se vezuje uz prirodu vojnog poziva, ali s obzirom na obilježja djelatnog sastava hrvatskog obrambenog sustava, u okviru ovog rada potrebno je istaknuti još nekoliko važnih pojedinosti. Kao prvo, hrvatska se vojska stvarala u uvjetima rata, većinski dio djelatnog sastava su njegovi sudionici i po nekim se proživljenim iskustvima i značajkama ne razlikuju od razvojačenih branitelja. S druge strane, od 1999. godine hrvatski vojnici aktivno sudjeluju u međunarodnim vojnim operacijama, a istraživanja sudionika tih operacija upućuju na opadanje bračnog zadovoljstva, porast namjera rastave braka i porast nasilja u obiteljima, osobito tijekom prve godine po povratku iz misije (Hoge i sur., 2004.). S profesionalizacijom i ulaskom u NATO, u hrvatskom obrambenom sustavu značajno su se povećali psihički zahtjevi prema vojnicima i njihovim obiteljima. Newby i sur. (2005.) navode kako je pojava nasilja u obiteljima vojnika povezana s nizom čimbenika koji povećavaju doživljaj stresa prije, tijekom i nakon odlaska vojnika u vojnu operaciju. Novija istraživanja (McCarroll i sur., 2008.; Rentz i sur., 2007.: Thomsen i sur., 2014.; prema Milner, 2015.) ne potvrđuju jednoznačnu povezanost iskustva sudjelovanja u suvremenim vojnim operacijama s pojavom zlostavljanja djece. Međutim, s obzirom na emocionalne promjene kroz koje prolaze vojnici (emocionalni ciklus povezan s misijom), može se pretpostaviti da postoje kritična razdoblja u kojima je vjerojatnost pojave zlostavljanja djece veća. To se prije svega odnosi na razdoblje prije odlaska i razdoblje nakon povratka iz misije (Milner, 2015.). Osim toga, postoje nalazi o ukupnom porastu zlostavljanja djece od strane civilnog roditelja (majke) tijekom trajanja misije (Gibbs i sur., 2007.; McCarthy i sur., 2015., prema Milner, 2015.). Dugotrajne vojne operacije povećavaju doživljaj majčina stresa, smanjuju razinu socijalne potpore i obiteljsko zajedništvo što sve predstavlja rizične čimbenike za pojavu nasilja nad djecom te povećavaju vjerojatnost njegova pojavljivanja tijekom sudjelovanja roditelja vojnika u misije. S druge strane, povratak partnera iz vojne misije predstavlja stres za oba roditelja i povećava vjerojatnost njihovog nasilničkog ponašanja prema djetetu (Milner, 2015.). 
Uz svaku raščlambu fenomena obiteljskog nasilja nameće se i pitanje vjerodostojnosti dostupnih pokazatelja o ukupnom broju počinjenih djela i njihovim obilježjima. Iz tih se razloga prethodno navedeni podaci o relativno malom broju evidentiranih slučajeva nasilja u obiteljima hrvatskih djelatnih vojnika mogu dvojako interpretirati, odnosno mogu, ali i ne moraju odgovarati stvarnom stanju. U vojsci vrijede strože norme ponašanja koje mogu smanjiti pojavu nasilja jer ozbiljno kršenje vojne stege, kriminalno ponašanje, psihički problemi i/ili zloporaba sredstava ovisnosti predstavljaju razloge za otpuštanje iz vojne službe. S druge pak strane, stroge norme mogu i smanjiti vjerojatnost prijavljivanja slučajeva nasilja. Prestanak vojne službe i gubitak sigurnih prihoda jednog hranitelja u obitelji veliki je obiteljski rizik u društvu opterećenom krizom i visokom stopom nezaposlenosti te može biti dovoljan razlog za šutnju. Osim toga, nasilje u obitelji je lako »sakriti« i teško dokazati jer se događa u privatnom prostoru, nedostupnom za »vanjske« intervencije. Neprijavljivanje nasilja također može biti odraz društvenih stavovi i prevladavajućih mitova o nasilnim vezama koji pridonose socijalnom prihvaćanju ili toleriranju obiteljskog nasilja (Ajduković, 2004.b; Gracia i Lila, 2015.). Ovdje je važno istaknuti da su profesionalni vojnici, čak i kad su svjesni postojanja određenih psihičkih poteškoća, neskloni traženju stručne pomoći, najčešće zbog straha od stigmatizacije i/ili od negativnih karijernih posljedica (Gerlock, 2004.; Sudom, Zamorski i Garber, 2012.).

$\mathrm{Na}$ žalost, službena statistika o razmjerno rijetkoj zastupljenosti nasilja u vojnim obiteljima pogoduje i slaboj senzibilizaciji zapovjednika o stvarnim razmjerima problema, potrebi preispitivanja uzroka i poduzimanja mjera na postrojbenoj i organizacijskoj razini, što može biti i odraz vojnoorganizacijske kulture (Clark i Messer, 2006.). Osim toga, mali broj prijava može pridonijeti atribuiranju uzroka takvog ponašanja individualnim čimbenicima, a ne interakciji različitih nepovoljnih okolnosti vezanih uz prirodu vojnog poziva. Na taj se način lako previđa odgovornost vojne organizacije za stanje i potrebe svoga osoblja, obiteljsko se područje percipira kao privatno, a obiteljski problemi kao isključiva odgovornost njezinih članova. Opravdano je pretpostaviti da takva razmišljanja ne vrijede samo za donositelje vojnih odluka, već i za ukupno vojno osoblje i njihove obitelji. To bi mogao biti jedan od ključnih razloga zašto je, unatoč nastojanjima psihološke struke i iskustvima drugih vojski, postojeći sustav psihološke prevencije i potpore u Hrvatskoj vojsci namijenjen isključivo vojnom osoblju, a ne i članovima njihovih obitelji. Iskustva drugih zemalja članica NATO saveza pokazuju da je bez uključivanja obitelji u sustav psihosocijalne potpore teško u vojnika razvijati otpornost na stres $\mathrm{i}$ upravljanje stresom (RTO NATO, 2008.). Vojske koje su unutar programa psihološke prevencije i potpore razvile i ciljane programe namijenjene obiteljima, lakše zahvaćaju sve psihosocijalne potrebe svojih pripadnika, pa samim time mogu bolje preventivno djelovati i u slučajevima obiteljskog nasilja.

\section{6 članci}


Primjer dobro osmišljenog i učinkovitog rada s obiteljima profesionalnih vojnika je sveobuhvatni Family Advocacy Program koji je američka vojska utemeljila još 1981. godine. Njegova je temeljna zadaća promoviranje zdravih, nenasilnih obitelji i zajednica preko različitih mjera pomoći, preventivnih i tretmanskih intervencija te suradnje u zajednici. Program uključuje mjere primarne, sekundarne i tercijarne prevencije pojave nasilničkog ponašanja. Primarna se prevencija odnosi na promoviranje općeg zdravlja i sprječavanje štetnog djelovanja stresa, sekundarna prevencija na otkrivanje ranih pokazatelje stresa i obitelji pod povećanim rizikom (primjerice »nove« obitelji i roditelje) te sprječavanje daljnje eskalacije problema dok tercijarna razina uključuje psihosocijalne intervencije i tretmane namijenjene žrtvama i počiniteljima nasilja (Clark i Messer, 2006.; Travis, Heyman i Smith Slep, 2015.). Kao dio programa razvijen je središnji registar za prikupljanje i analizu podataka te odbor koji čini multidisciplinarni tim vojnih stručnjaka (Rentz i sur., 2006.). Programe namijenjene pružanju psihosocijalne potpore obiteljima djelatnih vojnika razvijaju i vojske većina zemalja NATO saveza.

Nasuprot tomu, sustav psihološke prevencije i potpore u hrvatskom obrambenom sustavu ima vrlo ograničene mogućnosti i dosege. Nositelji programa su vojni psiholozi i nema drugih stručnjaka koji bi se sustavno bavili psihološkom dobrobiti vojnog osoblja i članova njihovih obitelji (socijalnih radnika, psihijatara) čime je limitirana njegova djelotvornost i onemogućen multidisciplinarni pristup. Naglasak je na primarnoj i sekundarnoj prevenciji negativnih posljedica stresa (formalna i neformalna edukacija, savjetovanje, psihološke krizne intervencije) i dominantno je usmjeren samo na vojno osoblje, čime je znatno otežano sagledavanje svih psihosocijalnih problema i rizika djelatne vojne populacije, uključujući i pojavu nasilja u obiteljima djelatnih vojnika.

\section{ZAKLJUČAK}

Nasilje u obitelji i bliskim odnosima društveno je neprihvatljivo ponašanje ne samo u općoj, već i u vojnoj populaciji te je zbog toga potrebno odgovorno pristupiti prevenciji i ublažavanju njegovih štetnih posljedica na svim razinama. Zbog iskustva Domovinskog rata, broja razvojačenih branitelja i broja aktivnih vojnika, velik je broj hrvatskih obitelji koje su izravno ili neizravno povezane s vojskom. Nasilje u obiteljima i bliskim odnosima aktivnih vojnika i vojnih veterana posljedica je konstelacije socijalnih rizika kojima je izložena vojna populacija i izazov je svakom, pa tako i hrvatskom društvu. U skladu s konstruktivističkim načelima u radu s vojnom populacijom i njihovim obiteljima važno je razvijati praksu koja podrazumijeva partnerske odnose svih dionika i ispravno korištenje jezika. Nužno je da se socijalna stvarnost definira kroz zajednički napor pogođenih pojedinaca, stručnjaka i 
donositelja odluka. Pri tomu je osobito važno na koji način sami korisnici konstruiraju stvarnost i poteškoće kojima su izloženi te da se u procesu njihova osnaživanja vodi računa o njihovim kapacitetima, mogućnostima, vizijama i vrednotama. Nasilje u obitelji vojnika može predstavljati individualni i obiteljski problem te rizik članovima obitelji, na razini zajednice zasigurno predstavlja socijalni rizik, dok je na državnoj razini izazov institucijama zaduženima za psihosocijalnu skrb.

Za promjenu u pristupu pojavi nasilja u obiteljima nužno je prije svega početi se baviti uzrocima problema, a ne samo njegovim posljedicama. $U$ slučaju obiteljskog i nasilja u bliskim vezama u vojnoj populaciji ključno je poboljšati nepovoljne životne okolnosti koje pogoduju njegovu pojavljivanju. Ključnu ulogu u pristupanju problemu nasilja u vojnim obiteljima imaju Ministarstva branitelja i Ministarstva obrane. Ministarstvo branitelja je odlukom o osnivanju Nacionalnog centra za psihotraumu stvorilo pretpostavke za podizanje opće kvalitete življenja i podupiranje potpune psihosocijalne reintegracije svih sudionika i stradalnika rata, uključujući i povratnike iz međunarodnih vojnih i redarstvenih operacija te članove njihovih obitelji. Međutim, učinkovitost projekta upitna je ukoliko na svim razinama društva ne zaživi u praksi i ne potakne interdisciplinarnu suradnju, edukaciju $i$ angažman svih civilnih $i$ vojnih snaga. $U$ smislu preventivnog djelovanja osobito je važna uloga Ministarstva obrane. U hrvatskom obrambenom sustavu nužno je unaprjeđenje sustava psihološke prevencije i potpore koji bi trebao omogućiti bolju komunikaciju vojnika i njihovih obitelji sa stručnjacima odnosno interdisciplinarnim timovima. Na taj bi se način bolje identificirali svi socijalni rizici i problemi, uključujući i nasilničko ponašanje. U pristupu problemu nasilja nužno je krenuti od identifikacije i evidentiranja svih oblika nasilja u obitelji. Ključna su pitanja tko i na koji način procjenjuje i dokumentira slučajeve nasilja, utječe li evidencija nasilja na počinjenje i prijavu nasilja, koja su obilježja počinitelja i žrtvi, gdje se i kada ono događa te rezultira li nasilje ikakvim psihosocijalnim mjerama. Evidentna je potreba za promjenom postojeće vojne kulture u smislu organizacijskih i liderskih čimbenika koji predstavljaju zapreku razvijanju i korištenju različitih izvora psihosocijalne potpore unutar vojnog sustava.

Psihološka dobrobit i uspješna reintegracija vojnika u civilni život nije samo individualno i obiteljsko pitanje, već i odgovornosti vojne organizacije, a predstavlja i pitanje nacionalne sigurnosti. Ono je osim toga i pitanje lokalne zajednice u kojoj se trebaju stvoriti uvjeti za kontinuiranu potporu obiteljima vojnika sukladno njihovim stvarnim potrebama. Nažalost, u hrvatskom se društvu vojska još uvijek percipira kao zatvorena institucija specifične politike i prakse, a psihosocijalni problemi vojnog osoblja nisu prioritet ili su nezanimljivi civilnim stručnjacima. Možda je to razlog malom broju primjera uspješne civilno-vojne suradnje u tom području. Može li se to konačno promijeniti?

\section{8 članci}




\section{LITERATURA}

1. Ajduković, M. (2004a). Psihosocijalne intervencije s počiniteljima nasilja u obitelji. Hrvatski ljetopis za kazneno pravo i praksu, 11 (1), 171-199.

2. Ajduković, M. (2004b). Mitovi i činjenice o nasilju nad ženama. U: Ajduković, M. \& Pavleković, G. (ur.), Nasilje nad ženama u obitelji (2. dopunjeno izdanje). Zagreb: Društvo za psihološku pomoć, 43-53.

3. Ajduković, M. (2008). Socijalni problemi, socijalni rizici i suvremeni socijalni rad. Revija za socijalu politiku, 15 (3), 395-414.

4. Ajduković, D. \& Ajduković, M. (2010). Nasilje u obitelji: Što zdravstveni djelatnici mogu učiniti? Medicina Fluminensis, 46 (3), 292-299.

5. Anton, S. (2005). Društveno funkcioniranje oboljelih od posttraumatskog stresnog poremećaja i radna sposobnost. Društvena istraživanja, 4-5 (78-79), 853-865.

6. Begić, D. \& Jokić-Begić, N. (2001). Aggressive behavior in combat veterans with PTSD. Military Medicine, 166 (8), 671-676.

7. Begić, D. \& Jokić-Begić, N. (2007). Heterogeneity of posttraumatic stress disorder symptoms in Croatian war veterans: Retrospective study. Croatian Medical Journal, 48 (2), 133-139.

8. Buljan Flander, G. (2007). Izloženost djece nasilju: Jesmo li nešto naučili? U: Kolesarić, V. (ur.), Psihologija nasilja i zlostavljanja - Zbornik radova znanstvenostručnog skupa Psihologija i nasilje u suvremenom društvu. Osijek: Filozofski fakultet, 45-52.

9. Clark, J. C. \& Messer, S. C. (2006). Intimate partner violence in the U.S. military: Rates, risks, and responses. In: Castro, C. A., Adler, A. \& Britt, T. W. (eds.), Military life: The psychology of serving in peace and combat: The military family. Westport, C: Praeger Security International, 193-219.

10. European Union Agency for Fundamental Rights (2014). Violence against women: An EU-wide survey, main results. Luxembourg: Publication Office of the european Union.

11. Foy, D. (1994). Liječenje posttraumatskog stresnog poremećaja: Spoznajno bihevioralni postupci. Jastrebarsko: Naklada Slap.

12. Gerlock, A. A. (2004). Domestic violence and post-traumatic stress disorder severity for participants of a domestic violence rehabilitation program. Military Medicine, 169 (6), 470-474.

13. Gracia, E. \& Lila, M. (2015). Attitudes towards violence against women in the EU. Luxembourg: Publication Office of the European Union.

14. Gustović-Ercegovac, A. \& Komar, Z. (1994). Socijalna reintegracija hrvatskih vojnika s problemima prilagodbe. Socijalna reintegracija hrvatskih vojnika i njihovih obitelji. Zagreb: MORH-IPDI. 
15. Hoge, C. W., Koffman, R. L., Castro, C. A., Messer, S. C., McGurk, D. \& Cotting, D. I. (2004). Combat duty in Iraq and Afghanistan, mental health problems, and barriers to care. The New England Journal of Medicine, 351 (1), 13-22.

16. Holbrook, J. (2011). Veterans' courts and criminal responsibility: A poblem-solving history and aproach to the liminality of combat trauma. In: Kelly, D. K., Howe-Barksdale, S. \& Gitelson, D. (eds.), Treating young veterans: Promoting resilience through practice and advocacy. New York: Springer Publishing Company, LLC., 259-300.

17. Kalebić Jakupčević, K. \& Ajduković, M. (2011). Risk factors of child physical abuse by parents with mixed anxiety-depressive disorder or posttraumatic stress disorder. Croatian Medical Journal, 52 (1), 25-34.

18. Klasnić, K. (2011). Ekonomsko nasilje nad ženama u intimnim vezama u hrvatskom društvu - konceptualne pretpostavke. Socijalna ekologija, 20 (3), 335-355.

19. Komar, Z. \& Vukušić, H. (1999). Post-traumatic stress disorder in Croatian war veterans: Prevalence and psychosocial characteristics. Zagreb: Croatian Academy of Sciencs and Art.

20. Komar, Z. \& Koić, E. (2015). Samoubojstva hrvatskih branitelja u Zagrebu i Hrvatskoj. Zagreb: Gradski ured za branitelje.

21. Lončar, M., Dijanić Plašć, I., Skorušek-Blažičko, S., Marinković-Danilović, Z., Kraljević, K., Benić, N. \& Božonja, F. (2014). Nacionalni centar za psihotraumu pri Kliničkom bolničkom centru Zagreb. Socijalna psihijatrija, 42 (2), 75-79.

22. Milner, J. S. (2015). Child maltreatment in United States military families. Child Abuse \& Neglect, 47, 102-113.

23. Ministarstvo branitelja (2014). Nacionalni program psihosocijalne i zdravstvene pomoći sudionicima i stradalnicima Domovinskog rata, Drugog svjetskog rata te povratnicima iz mirovnih misija. Zagreb: Ministarstvo branitelja Republike Hrvatske.

24. Newby, J. H., Ursano, R. J., McCarroll, J. E., Liu, X., Fullerton, C. S. \& Norwood, A. E. (2005). Postdeployment domestic violence by U. S. Army soldiers. Military Medicine, 170 (8), 643- 647.

25. O'Donnell, C., Cook, J. M., Thompson, R., Riley, K. \& Neria, Y. (2006). Verbal and physical aggression in World War II former prisoners of war: Role of posttraumatic stress disorder and depression. Journal of Traumatic Stress, 19 (6), 859-866.

26. Otročak, D. (2003). Interpretacija rezultata istraživanja nasilja nad ženama u Republici Hrvatskoj. Zagreb: Autonomna ženska kuća.

27. Pavlina, Ž., Filjak, T. \& Bender-Horvat, S. (2000). Bojni stres. U: Pavlina, Ž. \& Komar, Z. (ur.), Vojna psihologija - Priručnik za hrvatske časnike, (knjiga prva). Zagreb: MORH, 379-427.

28. Quinn, T. \& Quinn, E. (2011). Trauma and the developmental course of PTSD postdeployment. In: Kelly, D. K., Howe-Barksdale, S. \& Gitelson, D. (eds.), Tre- 
ating young veterans: Promoting resilience through practice and advocacy. New York: Springer Publishing Company, 23-32.

29. Rentz, E. D., Martin, S. L., Gibbs, D. A., Clinton-Sherrod, M., Hardison, J. \& Marshall, SW. (2006). Family violence in the military: A review of the literature. Trauma, Violence \& Abuse, 7 (2), 93-108.

30. RTO NATO (2008). Stress and psychological support in modern military operations. NATO: Final Report of Task Group HFM 081.

31. Segal, M. W. (1989). The nature of work and family linkages: A theoretical perspective. In: Bowen, G. K. \& Orthner, D. K. (eds.), The organization family: Work and family linkages in the us military. New York: Praeger, 3-36.

32. Sesar, K. \& Dodaj, A. (2014). Čimbenici rizika za nasilje u partnerskim vezama. Socijalna psihijatrija, 42 (3), 162 - 171.

33. Straits-Tröster, K., Gierisch, J. M., Calhoun, P. S., Strauss, J. L., Voils, C. \& Kudler, H. (2011). Living in transition: Young veterans' health and the postdeployment shift to family life. In: Kelly, D. K., Howe-Barksdale, S. \& Gitelson, D. (eds.), Treating young veterans: Promoting resilience through practice and advocacy. New York: Springer Publishing Company, LLC., 153-172.

34. Sudom, K., Zamorski, M. \& Garber, B. (2012). Stigma ad barriers to mental health care in deployed Canadian Forces personnel. Military Psychology, 24 (4), 414-431.

35. Taff, C. T., King, L. A., King, D. W., Leskin, G. A. \& Riggs, D. S. (1999). Partners'ratings of combat veterans' PTSD symptomatology. Journal of Traumatic Stress, 12 (2), 327-324.

36. Tjaden, P. \& Thoennes, N. (2000). Extent, nature, and consequences of intimate partner violence: Findings from the national violence against women survey. Washington, D. C.: Department of Justice, Publications No.

37. Travis, W. J., Heyman, R. E. \& Smith Slep, A. M. (2015). Fighting the battle on the home front: Prevention and intervention of child maltreatment for the military family. Child Abuse \& Neglect, 47, 114-123.

38. Trlek, M., Pavlina, Ž. \& Trut, V. (2003). Povratak bojovnika iz rata. U: Pavlina, Ž. \& Komar, Z. (ur.), Vojna psihologija - priručnik za hrvatske časnike, knjiga druga. Zagreb: $\mathrm{MORH}, 287-332$.

39. Vračić, I. (2005). Odnos posttraumatskih stresnih reakcija i općih psihopatoloških tendencija kod sudionika Domovinskog rata. Magistarski rad. Zagreb: Filozofski fakultet Sveučilišta u Zagrebu.

40. Wallace, H. (2004). Family violence: Legal, medical, and social perspectives. Boston: Allyn \& Bacon.

41. World Health Organization (2002). World report on violence and health. Geneva: WHO. 
42. World Health Organization (2013). Global and regional estimates of violence against women: Prevalence and health effects of intimate partner violence and non-partner sexual violence. Geneva: WHO.

43. Žganec, N. \& Miljenović, A. (2011). Multikulturalizam u socijalnom radu. Revija za socijalnu politiku, 18 (3), 311-330.

Vesna Trut

Ministry of Defence of the Republic of Croati.

Croatian Defence Academy »Dr. Franjo Tuđtman«

\section{VIOLENCE IN FAMILIES AND INTIMATE RELATIONS OF WAR VETERANS AND ACTIVE MILITARY PERSONNEL: RISKS FACTORS AND PREVENTION POSSIBILITIES}

\section{ABSTRACT}

This article analyses available indicators and evaluates the presence of violent behavior in families of Croatian war veterans and active military personnel. Based on available data and the specificity of the military profession, key risk factors for the appearance of family violence in the military population are analyzed. Special attention is given to stressors of the military profession that negatively affect the psychological and physical health of military personnel as well as the overall functioning of families and health effects of family's members. Due to experiences from the Homeland War, characteristics of the Croatian military population, their specificities and possible connection to the appearance of violent behavior are critically examined. Special emphasis is placed on the need and possibility for preventive action in removing or mitigation of this unwanted behavior at various social levels.

Key words: family violence, intimate violence, active military personnel, war veterans, risk factors. 